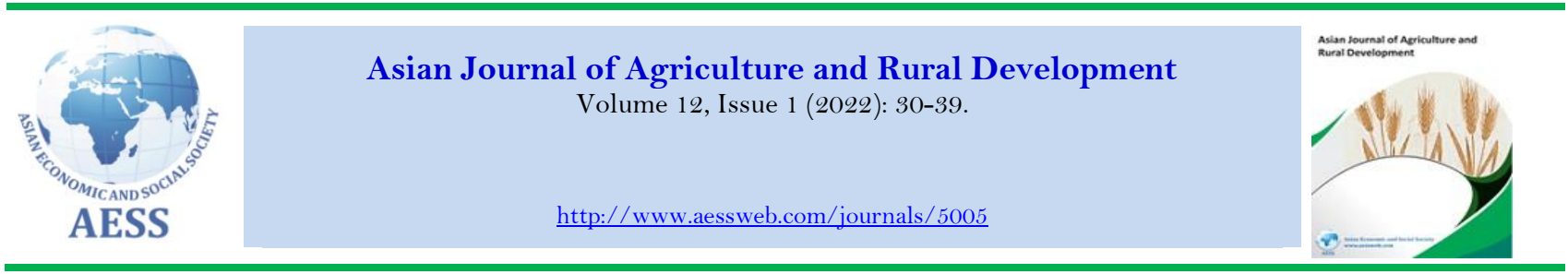

\title{
ASSESSMENT OF TURKEY FARMING MANAGEMENT PRACTICES BY SMALL-SCALE RURAL FARMERS IN EASTERN NIGERIA
}

\author{
Oyeagu Chika Ethelbert ${ }^{\mathrm{a}}$ \\ Iwuchukwu Juliana Chinasa ${ }^{b}$ \\ iD Falowo Andrew Bamidele ${ }^{\mathrm{c}}$ \\ D Akuru Eunice Amaka ${ }^{d}$ \\ (iD) Adetunji Adewole Tomiwa ${ }^{a}$ \\ iD Lewu Francis Bayo ${ }^{a}$ \\ (iD) Yiseyon Sunday Hosu ${ }^{\mathrm{e}, \mathrm{f}}$ \\ (iD) Idamokoro Emrobowansan \\ Monday, ${ }^{\mathrm{e}, \mathrm{t}}$
}

Article History
Received: 18 February
Revised: 14 January 202
Accepted: 31 January 2
Published: 28 February
Keywords
Management practices
Rural areas
Smallholder farmers
Local families
Production
Turkey farming.

\author{
${ }^{a}$ Department of Agriculture, Faculty of Applied Sciences, Cape Peninsula University of \\ Technology, Wellington Campus, Cape Town, South Africa. \\ ${ }^{b}$ Department of Agricultural Extension, University of Nigeria, Nsukka, Nigeria. \\ 'Department of Animal Science, Adekunle Ajasin University, Akungba-Akoko, Ondo State, \\ Nigeria. \\ ${ }^{d}$ Department of Animal Science, University of Nigeria Nsukka Nigeria. \\ 'Small-Scale Agribusiness and Rural Non-farm Enterprise, Niche Area, Walter Sisulu \\ University, South Africa. \\ ${ }^{\top}$ Faculty of Commerce and Administration, Department of Economics and Business Sciences, \\ Walter Sisulu University, South Africa.
}

ه

\begin{abstract}
A survey of rural turkey farmers was conducted in three villages in the Eastern part of Nigeria, namely: Amukwa, Amaeze and Nguru. The aim of the study was to assess the prevailing management and production practices of turkey farmers in the area. Information obtained included flock size, reasons for keeping birds, breeding and management practices among others. The multistage random sampling method was used to collect information from 180 respondents. Results obtained revealed variability in response among flock sizes (1-20), with most (90\%) respondents being part-time farmers. Mean scores, in terms of the level of adoption of standard management practices by turkey farmers, were given as cleaning and disinfection of pen before restocking $(\bar{x}=4.60)$, removal of droppings $(\bar{x}=4.57)$, and changing and replacement of litters $(\bar{x}=4.4)$. Beak trimming $(\bar{x}=1.27)$ was the lowestranked farm practice by farmers. It was concluded that the management practices and production of turkey in the study area are below standard when compared to those in developed societies. Adequate support for farmers in terms of finance and regular training, among others, by relevant agencies including the government may help improve the production of turkey in the area.
\end{abstract}

Contribution/Originality: This study contributes in the existing literature on the prevailing management practice of local turkey-farming among rural communities in the Eastern Region of Nigeria.

DOI: $10.55493 / 5005 . v 12 \mathrm{i} 1.4428$

$\operatorname{ISSN}(\mathrm{P}):$ 2304-1455/ ISSN(E): 2224-4433

How to cite: Oyeagu Chika Ethelbert --- Iwuchukwu Juliana C --- Falowo Andrew Bamidele --- Akuru Eunice Amaka --- Adetunji Adewole T --- Lewu Francis B --- Yiseyon Sunday Hosu --- Idamokoro Emrobowansan Monday (2022). Assessment of Turkey Farming Management Practices by Small-Scale Rural Farmers in Eastern Nigeria. Asian Journal of Agriculture and Rural Development, 12(1), 30-39. 10.55493/5005.v12i1.4428 


\section{INTRODUCTION}

Turkey (Meleagris gallopavo) production is an integral part of poultry production that forms an important component of Nigeria's livestock sub-sector. The turkey industry in Nigeria has risen from 1.5 to 2 million tons of meat locally per annum. This rapid growth in the industry was made possible by intensification of production and development of large breeds with standard live weights ranging from 15 to $17 \mathrm{~kg}$ for males and 8 to $10 \mathrm{~kg}$ for females, some of which were produced from homesteads (Ajala \& Adesehinwa, 2006). Turkey is one of the largest animals of the poultry species, reaching 10-15.8 kg live weight (Mozdziak, 2019). In Nigeria, large strains/hybrids of up to 8-12 kg live weight and of white plumage are reared (Ironkwe \& Akinola, 2010). The economic potential of local turkeys cannot be overlooked considering the huge foreign exchange implication of the importation of improved exotic stock and genotype-environment interaction, which leads to considerable loss of fitness of exotic stock (Nwagu, 2002). Turkeys are natural foragers and can be kept as scavengers. Turkeys can be reared under three different management systems, namely: intensive, semi-intensive and extensive. Ironkwe and Akinola (2010) in their study reported that turkeys are easy to manage as domestic animals, with relatively high turnover and rapid returns on capital invested. Turkey production is a means of livelihood and a way of achieving some level of economic independence in Nigeria. Its production is carried out in all parts of the country with little or no religious, social or cultural inhibitions associated with its consumption. Specifically, investment in turkey enterprises is attractive because the production cost per unit is low, with a short generation interval compared to other types of livestock such as ruminants. Owing to these obvious advantages of turkey production, large number of farmers, both men and women, have ventured into turkey production mostly for income generation, besides meeting the protein needs of their households. Turkey production for meat and eggs are practiced by both urban and semi-urban dwellers.

Turkey production in Nsukka (Eastern Nigeria) is relatively low compared to some other poultry species (broilers and layers). Furthermore, sales and marketing of turkeys in the area are carried out by residents, with the highest sales recorded during festive periods such as Easter, Christmas and New Year. Conversely, the potential of turkey production in the area if properly harnessed will increase farmer's income and improve household food and nutrition security, thereby improving their livelihood. Meanwhile, seasonal and shortage of quality feed, low breed quality, bad management practices, and poor health constitute the limiting factors to rapid growth and development of this poultry subsector. These problems are, however, surmountable if the prevailing poor extension services to poultry farmers are materially improved (Ayanda, 2013). On the other hand, poor management and extension practices may thwart the dream of achieving self-sustenance and improved production of the livestock in the near future. It is desirable to improve on the tempo of extension services as one of the strategies used to increase poultry production at the rural level. Sinkaiye (2005) equates help in extension to empowering all members of the farm household to ensure holistic development. Addressing the poor state of poultry extension services in Nigeria will be pertinent at this material time in order to improve skills, management practices and knowledge of poultry producers, and to increase their access to farm inputs and credit. These in turn may translate to sustainable growth of the industry, provide quality and affordable animal protein for citizens and increase producers' income and thus help to alleviate poverty in the South-eastern part of Nigeria, and in other parts of the country. Therefore, this study is intended to assess and document the prevailing turkey management practices by small-scale rural farmers in Eastern Nigeria in order to identify possible intervention approaches.

\section{MATERIALS AND METHODS}

\subsection{Ethical Considerations}

Ethical principles were taken into consideration during the study, to adhere to the national and international standards governing research of this nature with regards to the use of research animals and humans. Permission was obtained from the Ethical Clearance Committee of the University of Nigeria, Nsukka, Nigeria.

\subsection{Study Area}

The study was conducted in Nsukka town, Enugu State, Eastern Nigeria. The town, as shown in Figure 1, is made up of three major communities: Ihe-Owere, Mkpunano, and Nru. Nsukka lies at latitude $06^{\circ} 22^{1}$ north and longitude $07^{\circ} 24^{1}$ east. It has an annual rainfall range of 1567-1847 $\mathrm{m}$. Mean minimum and maximum daily temperatures are 21 ${ }^{\circ} \mathrm{C}$ and $30.3{ }^{\circ} \mathrm{C}$, respectively. Relative humidity ranges from 46.7\% to 76.2\% (Ugwu, Ogbu, \& Amaechi, 2011). Nsukka is in the humid tropical rainforest zone of South-eastern Nigeria.

\subsection{Data Collection}

The population of Nsukka town was estimated at 95,510 in 1990 (NPC, 2006). The multi-stage sampling technique was used to select respondents for the study. From the three communities that make up Nsukka, two (Ihe-Owere and Mkpunano) were selected and used for the study. In Ihe-Owere, Amukwa and Amaeze sub-communities were randomly selected. Mkpunano has only one sub-community, called Nguru, which was selected as the third study area. A total of 180 questionnaires were distributed to turkey farmers in the three sub-communities used for the study. In each subcommunity, 60 respondents (turkey farmers) were purposively selected among turkey farmers in the area and questionnaires were administered to them.

\subsection{Data Analysis}

Data analysis was done using IBM SPSS Statistic 24. Frequencies were used to analyze the demographic and socioeconomic status of turkey farmers. In order to ascertain the level of adoption of standard turkey management practices, a five-point Likert-type scale was used: unaware $=0$, aware $=1$, aware but no detail $=2$, detail but not interested $=3$, 
have personally used $=4$, and still in use $=5$. The maximum total of the Likert scale $=15$ and the cut-off point was obtained by using the mean of the nominal values, which is 3.0. Any variable with mean score of 3.0 and above was regarded as practice used, while variables with mean score $<3.0$ were regarded as otherwise.

\section{RESULTS AND DISCUSSION}

\subsection{Socio-Economic Characteristics of Turkey Farmers}

Socio-economic characteristics of smallholder turkey farmers in the study area were examined with respect to age, level of education, sex, farming status, and marital status, as presented in Table 1, while flock size is presented in Table 2. These socio-economic variables were specifically selected in order to determine the category of persons involved in the poultry business and their capacity in terms of number of birds owned for any policy intervention.

Table 1. Personal characteristics of turkey farmers $(n=180)$

\begin{tabular}{|c|c|}
\hline Household head characteristics & Percentage (\%) \\
\hline \multicolumn{2}{|l|}{ Age (years) } \\
\hline $21-30$ & 10.0 \\
\hline $31-40$ & 36.7 \\
\hline $41-50$ & 30.0 \\
\hline 51 and above & 23.3 \\
\hline \multicolumn{2}{|l|}{ Educational status } \\
\hline No education & 0.0 \\
\hline FSLC & 16.7 \\
\hline WAEC/GEC/SSCE & 40.0 \\
\hline OND & 6.7 \\
\hline $\mathrm{NCE}$ & 6.7 \\
\hline Degree/HND & 20.0 \\
\hline Higher degree & 10.0 \\
\hline \multicolumn{2}{|l|}{ Sex } \\
\hline Male & 26.7 \\
\hline Female & 73.3 \\
\hline \multicolumn{2}{|l|}{ Farming status } \\
\hline Full-time & 10.0 \\
\hline Part-time & 90.0 \\
\hline \multicolumn{2}{|l|}{ Marital status } \\
\hline Married & 70.6 \\
\hline Single & 29.4 \\
\hline
\end{tabular}

Table 1 shows that the majority of turkey farmers were female $(73.3 \%)$ as against male $(26.7 \%)$ in the study area, their age ranged between 31 and 40 years and educational status was up to WAEC/GCE/SSCE. The majority were married and part-time turkey farmers. This is an indication that turkey production is dominated by younger persons in the study area, implying that people within this age bracket are able-bodied that are likely to produce more, which means greater profit and higher protein intake. Again, young farmers are more likely to adopt new innovations than the older farmers. According to Onwumere and Obasi (2010), in their study of small-scale turkey production in Owerri (Imo State), Nigeria, it was reported that turkey production in the area was mostly practiced by people within the age bracket $31-50$ years $(56.0 \%)$.

Table-2. Distribution of respondents based on

\begin{tabular}{c|c} 
flock size $(n=180)$. & Percentage (\%) \\
\hline Flock size & 13.3 \\
\hline $1-5$ & 40.1 \\
\hline $6-10$ & 33.3 \\
\hline $11-15$ & 6.7 \\
\hline $16-20$ & 6.7 \\
\hline Above 20 & 100.0 \\
\hline Total &
\end{tabular}

The high level of female involvement in poultry production may be due to the quality time they spend with their families, and their natural interest in raising domestic birds (poultry farming), which is a typical practice for women in the study area. The extra money generated from poultry farming may empower them to support their men in some basic needs of the family in terms of feeding, medication, clothing and general welfare. This finding contradicts the study of Ja'afar-Furo and Gabdo (2010), who reported that more males (85.0\%) engaged in poultry farming than females $(15.0 \%)$ in the northern (Adamawa State) part of Nigeria. The present study also disagrees with the work of Apantaku 
(2006), who reported more males (77.0\%) than females (23.0\%) as owners of poultry enterprises in the southern (Lagos State) part of Nigeria. Likewise, Ajala and Adesehinwa (2006) in their study reported that there were more males $(66.0 \%)$ in the turkey production business in Zaria than females $(34.0 \%)$.

However, the findings of the current study are not different to what is obtainable in the rural extensive management system in which females are the dominant owners of poultry farms. Studies from Zimbabwe (Oakeley, 1999), Bangladesh (Nielsen, Roos, \& Thilsted, 2003), Kenya (Okitoi, Ondwasy, Obali, \& Murekefu, 2007), and Nigeria (Ogunlade \& Adebayo, 2009) indicate that females participate more than males in rural poultry production. They opined that men might not have the time to take care of turkey poults or growers since they are engaged in other moneymaking ventures while women can combine household activities with involvement in in part-time turkey production. The present result however, agrees with the findings of Brocholt and Odgaard (2009), who reported that poultry keeping is a skill of housewives in Nicaragua.

Likewise, the result from the present study showed that $100.0 \%$ of the respondents have acquired some form of formal education (Table 1). With this level of literacy among respondents, it is possible that they will readily adopt or accept any innovation aimed at improving turkey production in the area. The study of Musa, Dabai, Sakaba, and Sanchi (2015) showed that the level of education enables turkey farmers to accept innovations readily and to perform effectively in their management practices such as administration of drugs, vaccines, and feeds, as well as effective marketing of turkey. The level of education of turkey farmers could be a good platform through which extension services can be established in transferring research results for sustainable food production. This finding has, therefore, reflected the importance of education in agricultural production activities. The more an individual is exposed to any form of education, the more he/she will have a better understanding of their environment. This is in line with the findings of Onwumere and Obasi (2010), that the majority (83.0\%) of turkey farmers in Owerri (Imo state) had formal education. Furthermore, Table 1 reveals that greater proportions of turkey farmers do this on a part-time basis. The implication is that the majority of the turkey farmers have other jobs and that most are not dependent on it as their sole means of livelihood. The reason could be that civil servants or businesswomen in the study area are becoming more enterprising in turkey production as a source of income other than their main occupation, since they operate their turkey business on a part-time basis. This tallies with the findings of Ajala, Nwagu, Sekoni, and Adeshinwa (2007), who reported that the majority $(62 \%)$ of turkey farmers in Zaria (Kaduna state, Nigeria) were civil servants. The result also agrees with the findings of Amaza (2000), who reported that it is common for some farm households to engage in other non-farming activities to complement their farming occupation for their livelihood.

The results from Table 1 further reveal that the majority of turkey farmers were married, indicating that turkey production in the study area is most common among couples, which may help to generate more income and food for the family. The involvement of household members (married) in turkey farming may promote better chances of getting family labor in abundance for use on their farms than hired labor (Musa et al., 2015). The results in Table 2 show that the majority (40.1\%) of respondents owned fewer than 10 turkeys. Many respondents stated that since they raise turkey as a source of income, they usually sell off the young ones. However, some respondents attributed their small flock size to losses during the brooding stage (1-7 weeks). The study revealed that turkey production in Nsukka is on a small scale. The fact that up to $33.3 \%$ of respondents owned up to $11-15$ turkeys is an indication that if encouragement is given to farmers in the area, they may do better and it is only when they own large numbers of turkeys that they can be more responsive to improvements in turkey management practices. Therefore, extension administrators and policymakers should take steps in encouraging medium-scale turkey production in the area considering its numerous advantages over other livestock.

\subsection{Prevailing Turkey Management Practices by Small-Scale Rural Farmers}

Data on the prevailing management practices are presented in Table 3. Among all turkey management practices, cleaning and disinfection of pens before restocking $(\bar{x}=4.60)$, removal of droppings $(\bar{x}=4.57)$, and changing and replacement of litters $(\bar{x}=4.4)$ ranked highest (above the cut-off point of 3.0 and above) in terms of adoption. Beak trimming $(\bar{x}=1.27)$ was the lowest, showing that this practice was not applied by respondents.

Restriction and control of personnel, visitors, and equipment in the pen $(\bar{x}=2.83)$, and raising turkey and chicken together $(\bar{x}=2.73)$, were also used by respondents but to a lesser extent. This indicates that the respondents were aware of some standard practices and were more knowledgeable about certain standard management practices associated with poultry pen hygiene and litter. A modified battery cage system has been identified as the best management system for birds (Dikmen, Ipek, Şahan, Petek, \& Sözcü, 2016; Sherwin, Richards, \& Nicol, 2010). This practice, and certain other management practices such as beak trimming, had not been adopted in the study area. The reason for this may be attributed to the fact that most of these farmers kept small numbers of turkeys and thus may find it uneconomical to adopt some standard farm practices in raising their birds. One would have thought that small farm size would have encouraged debeaking, but this was not so according to our current findings. Extension agents should therefore encourage small-scale farmers to increase their flock size with the use of a battery cage system, and also promote the adoption of this system and other improved technologies that are currently not in use in the study area.

\subsection{Feed Management Practices and Feedstuffs Used for Turkey Farming}

Table 3 also shows that green vegetables mixed with silage was a highly adopted $(x=3.77)$ technology in the feeding and feedstuff for turkeys; meanwhile, research into the use of cheaper agro-industrial byproducts and waste 
materials at various levels of dietary inclusion for poultry has been intensified in the last few years to determine their efficiency of utilization in terms of growth and production (Adeniji \& Balogun, 2002; Oyeagu et al., 2015a; Oyeagu et al., 2016). The study conducted by Ja'afar-Furo, Balla, Tahir, and Haskainu (2008) revealed that chickens are either fed from household food remnants or are allowed to roam about for food. Farmers ( $\mathrm{x}=2.53)$ sometimes give birds feed at night, as observed in the current study. Local fish meal $(\mathrm{x}=1.87)$ was not used as food for turkeys by respondents. Local fish meal feeding is a means of alleviating the problem of feed cost without impairing the performance of birds (Bureau \& Cho, 2000).

Table-3. Distribution of respondents on the adoption of standard turkey management practices.

\begin{tabular}{|c|c|}
\hline Standard practices & Mean score* \\
\hline \multicolumn{2}{|l|}{ Management } \\
\hline Cleaning and disinfection of pen before restocking & 4.60 \\
\hline Removal of dropping at appropriate times & 4.57 \\
\hline Changing and replacement of litters & 4.40 \\
\hline Restriction/control of personnel, visitors, and equipment in the pen & 2.83 \\
\hline Turkeys and chickens cannot be raised together & 2.73 \\
\hline Beak trimming & 2.23 \\
\hline Usage of battery cage system & 1.00 \\
\hline \multicolumn{2}{|l|}{ Feed and feedstuffs } \\
\hline Green mixed with silage/from carrots and pumpkin & 3.77 \\
\hline Night feeding & 2.53 \\
\hline Local fish meal & 1.87 \\
\hline \multicolumn{2}{|l|}{ Water requirements } \\
\hline Usage of vitamins. Such as vitalyte in drinking water & 3.27 \\
\hline Vitalyte dosage & 3.0 \\
\hline Usage of hypochlorite, nitrofurazone and embazine-forte in drinking water & 1.13 \\
\hline \multicolumn{2}{|l|}{ Disease management } \\
\hline Importance of vaccination & 4.70 \\
\hline Vaccination against Newcastle disease & 4.67 \\
\hline Vaccination against fowl thyroid disease & 4.60 \\
\hline Vaccination against Gumboro disease & 4.43 \\
\hline Usage of sulphatide & 4.03 \\
\hline Correct sulphatide dosage & 4.03 \\
\hline Forage usage & 3.23 \\
\hline Correct forage dosage & 3.93 \\
\hline Adverse effect of nitrofurazonic drugs & 1.89 \\
\hline
\end{tabular}

It is under this system of management that family poultry formed the largest proportion of all livestock in Nigeria, which had a population of about 104 million about two decades ago (Ja'afar-Furo \& Gabdo, 2010). In this regard, improving poultry production will invariably greatly improve the economic base of most rural populations in the country, and in other nations with similar economies, especially if the target groups are women. According to Nielsen et al. (2003) in their study, assets (local available resources) controlled by women were used to improve the livelihood of household members and in particular that of children. The benefits derived from the improved form of this agriculture are numerous. In spite of serving as one of the major sources of readily available protein in rural areas, Amos (2006) and Ja'afar-Furo, Balla, and Yakubu (2007) reported that poultry enterprise yields rapid monetary turnover with prudent management. Similarly, Alabi and Aruna (2006) maintained that although output from the individual bird is low, family production systems are found to be economically efficient due to the low input requirement. The fact that over $70 \%$ of the population of Nigeria are resident in rural areas (Ayichi, 1995), engaging in poultry production will contribute to reducing the numbers of unemployed people in the country.

\subsection{Water Management Practices Adopted by Small-scale Turkey Farmers}

Data from Table 3 also revealed that the addition of vitamins, such as vitalyte, and antimicrobial agents, such as hypochlorite and nitrofurazone, in drinking water had mean scores of 3.27 and 1.13, respectively. However, the correct dosage of vitalyte in drinking water is $3.0 \mathrm{ml}$. It has been reported that vitalyte increases the appetite of birds and also serves as an anti-stress agent (Asli, Hosseini, Lotfollahian, \& Shariatmadari, 2007; Ciftci, Ertas, \& Guler, 2005). Farmers may therefore be employing these drugs because of harsh environmental conditions. Some research findings on the use of vitamin $\mathrm{C}$ and $\mathrm{E}$ in poultry feed showed that these agents can help to minimize reduction in poultry growth and egg production caused by heat stress (Biswas, Mohan, \& Sastry, 2010; Oguz, Oguz, Buyukoglu, \& Sahindokuyucu, 2010; Panda, Ramarao, Raju, \& Chatterjee, 2008; Pornpun, Bunchasak, Rakangthong, \& Poeikhampha, 2014; Renaudeau et al., 2012; Sobayo et al., 2008). Although according to medication prescriptions by manufacturers, hypochlorite, nitrofurazone and embazine-forte in poultry drinking water will help prevent fowl typhoid, fowl cholera, 
and intestinal infections, respectively. Conversely, the majority of the respondents from our findings did not use these medications for their birds, probably because of their high prices which most are unable to afford.

\subsection{Disease Management Practices as Practiced by Small-scale Turkey Farmers}

Information on disease management practices is presented in Table 3. The data show the importance of vaccination $(\bar{x}=4.70)$, vaccination against Newcastle disease $(\bar{x}=4.67)$, fowl typhoid disease $(\bar{x}=4.60)$, and Gumboro disease $(\bar{x}$ $=4.43$ ); these were the highest adopted practices, with the usage and dosage of sulphatide (4.03 and 3.93 mean score, respectively). Adverse effects of lurazoidone and nitrofurazone $(\bar{x}=1.89)$ were not known by farmers. However, since the medication was not used by these farmers, there will be no adverse effect of nitrofurazone on turkeys. Goetting, Lee, and Tell (2011) and Jacob, Wilson, Miles, Butcher, and Mather (2014) opined that laying birds experienced poor egg production as a result of the adverse effects of feeding nitrofurazone. The study conducted by Alam and Shaikh (2007) in Pakistan showed that even though poultry production is a very lucrative business there, the capital intensiveness in terms of cost of feed and medication is putting it out of reach for rural farmers. However, they also reported that a massive intervention by the government through the provision of liberal financing and credit, income tax exemption, duty-free import of grandparent and parent stocks, machinery, and poultry farm equipment, coupled with easy access to loan facilities from commercial and financial institutions, has allowed poultry enterprises to flourish and spread all over rural areas in that country. In Nsukka town (Eastern Nigeria), all respondents that were interviewed practiced a deep litter system.

\subsection{Possible Sources of Information to Turkey Farmers on Latest Improved Practices in Turkey Production}

The sources of information to turkey farmers on latest information of improved management practices in turkey production are presented in Table 4 . The result showed that veterinarians (90\%), neighbors, and friends (96.7\%) ranked as the most important sources of information (on improved management practices) available to turkey farmers. Newspapers and magazines, as well as extension agents, each contributed $33.3 \%$ as a source of information to turkey farmers. Other sources of information acquired by farmers to improve their management practices were radio and television (26.7\%), agricultural researches (26.7\%), and schoolchildren (13.3\%).

Table-4. Distribution of respondents according to sources of information.

\begin{tabular}{l|c|c}
\hline Source of information & Frequency & Percentage (\%) \\
\hline Fellow turkey farmers, neighbors and friends & 58 & 96.7 \\
\hline Veterinarians & 54 & 90.0 \\
\hline Written material in newspapers and magazines & 20 & 33.3 \\
\hline Agricultural extension agents & 20 & 33.3 \\
\hline Radio and television & 16 & 26.7 \\
\hline Agricultural researchers & 16 & 26.7 \\
\hline Children at school & 8 & 13.3 \\
\hline Note: Multiple responses, 100. &
\end{tabular}

The implication of this result is that veterinarians appear to be at the forefront as sources of information to farmers. It is therefore necessary for more livestock extension agents to be trained and recruited by the government. Interestingly, schoolchildren were also found to be sources of information. If schoolchildren are properly educated they can serve as a cheap and rapid means of information dissemination to farmers.

\subsection{Source of Extension Service}

The proportion of information on standard turkey management and production practices received from extension services was $33.0 \%$, as shown in Table 4, and these services were provided by agricultural development programs (ADPs). However, more than $80.0 \%$ of respondents never received any extension services. This finding is in agreement with Fawole (2006), who reported that although extension institutions and various sources of information exist in almost every developing country, their coverage of farming families remains very limited. Also, Ovwigho, Bratte, and Isikwenu (2009) stressed the importanvce of improving extension services in order to stimulate egg producers to adopt optimal chicken management systems (in Delta State, Nigeria). Steps should be taken to ensure that turkey farmers are exposed to extension services. Veterinarians in the area contributed significantly as sources of information to turkey farmers and equally provided substantial extension services, but there is need for cooperation between livestock extension agents and veterinarians for the purposes of improving turkey production in the area.

\subsection{Problems Hindering the Adoption of Standard Management Practices by Farmers}

The data in Table 5 illustrate the problems hindering the use of improved management practices by respondents and reveal that high cost of feed (90.0\%) and lack of funds for the establishment of turkey enterprises (80.0\%) were the major economic problems hindering the adoption of improved innovation by respondents. Atteh (2002); Kehinde, Babatunde, Ayoola, and Temowo (2006); and Oyeagu, Ani, Egbu, Udeh, and Omumuabuike (2015b) reported that feeding is a major item of cost in poultry production and that the high cost of poultry feed also results in general increase in the cost of production. The seasonal market demand for turkey $(66.7 \%)$ was encouraging. This finding agrees with the work of Musa et al. (2015), that sales and marketing of turkeys attain their peak during festive periods 
such as Easter, Christmas, and New Year. The low price of turkey in the area (6.7\%) and long maturity time $(3.3 \%)$ were also identified as problems faced by turkey farmers. This is in line with the study of Ja'afar-Furo and Gabdo (2010) that marketing of table-size birds is another major constraint suffered by the respondents in the area surveyed. Since poverty is so pronounced in both urban and rural areas (Kwaghe, Amaza, \& Ja'afar-Furo, 2009), demand for these birds is low in spite of the shift in consumption patterns from the other sources of livestock proteins to poultry products and fish due to changing tastes, costs, and income (Ja'afar-Furo et al., 2007). This result further supports the findings of Akbay (2006), who reported that high demand for animal-sourced proteins in Turkey had shifted from beef, veal, lamb, mutton, and goat to greater consumption of poultry and fish. Governments should provide funds in the form of loans and subsidies to encourage an increase in the scale of turkey production.

Table-5. Problems hindering the use of improved management practices by respondents.

\begin{tabular}{l|c}
\hline Problems & Percentage (\%) \\
\hline Economic and marketing problems & 90.0 \\
\hline High cost of feed & 80.0 \\
\hline Lack of funds for establishment of turkey farming & 66.7 \\
\hline Seasonal market demand for turkeys & 6.7 \\
\hline Low price of turkey in the area & 3.3 \\
\hline Low time of turnover or maturity & \\
\hline Management problems & 76.7 \\
\hline High mortality at 0-7 weeks of age & 56.7 \\
\hline Lack of accommodation & 40.0 \\
\hline Laborious nature of turkey management. & 30.0 \\
\hline Lack of technical know-how in turkey management & 20.0 \\
\hline Hostility and cannibalistic action of turkeys & 10.0 \\
\hline Endemic nature of coccidiosis & 3.3 \\
\hline Problems in detection of fertile eggs & 3.3 \\
\hline Non-availability of drugs & 3.3 \\
\hline Low number of poults produced after hatching & 3.3 \\
\hline Difficulty in feeding at younger age & \\
\hline Social problems & 73.3 \\
\hline Destruction of crops on the farm & 36.7 \\
\hline Theft of turkeys & 3.3 \\
\hline Lack of time for proper bird management & 3.7 \\
\hline Destruction of equipment and properties by birds & 56.7 \\
\hline Information problems & 3.3 \\
\hline Lack of information/advice & 3.3 \\
\hline Communication gap between extension agents and farmers & \\
\hline Insincerity of veterinarians & \\
\hline Note: Multiple responses: 10o. & \multicolumn{2}{|l}{} \\
\hline
\end{tabular}

\subsection{Management Problems of Small-scale Turkey Farmers}

Table 5 also shows that the major management problems hindering adoption by these respondents were high mortality at the brooding stage (76.7\%) and lack of accommodation (housing) (56.7\%). Accommodation (housing) for poultry birds is a problem in this area, probably because most respondents are tenants in rented accommodation. According to Mapiye and Sibanda (2005), inadequate housing, feeding, and health systems mostly result in predation, diseases, and chick mortality, which limits the expansion of village chicken production. The laborious nature of turkey management (40.0\%) also posed a problem in the production of these birds. Salo, Tadesse, and Hilemeskel (2016) listed some challenges (predators, theft, high mortality, diseases, etc.) in managing village chicken farms since the mode of production is extensive systems. Extension officers should look into these problems and suggest new technologies that can better solve them, especially that of mortality at the brooding stage (1-7 weeks of age). Mapiye and Sibanda (2005) suggested that more poultry extension officers should be equipped and deployed in rural locations to assist farmers with their challenges in poultry rearing, such as high mortality rate, diseases, hatching of eggs, housing, etc. Lack of technical know-how in turkey management (30.0\%), cannibalistic action of turkeys (20.0\%), and the endemic nature of coccidiosis in the study area $(10.0 \%)$ have the potential to cause problems in the adoption of innovation by respondents. Meanwhile, problems of detection of fertile eggs (3.3\%), non-availability of drugs (3.3\%), low number of poults produced after hatching $(3.3 \%)$, and difficulty in feeding younger birds (3.3\%) were the minor management problems hindering the adoption of standard management practices by respondents.

\subsection{Social Problems of Turkey Farmers that May Affect the Adoption of Standard Management Practice}

The major social problems preventing the adoption of standard turkey management practice were destruction of crops by stray animals (73.3\%) and theft of turkeys (36.7\%), as presented in Table 5 . This implies that most farmers operate a free range (extensive) system of management. Extension agents should therefore advise these farmers to adopt intensive management system to solve these problems. Lack of time to take care of birds (3.3\%) and destruction of equipment and property $(3.7 \%)$ were the least prevalent worries of respondents in the adoption of improved 
innovation. About $56.7 \%$ of the farmers indicted that lack of information and advice hindered them from adopting improved technologies, as can be seen in Table 5. This suggests that extension services did not reach the target group. This may be due to insufficient funds to provide transport, communication, and support materials to service all farmers' needs, as pointed out by Gildemacher et al. (2009) and Ogunniyi and Kehinde (2015). Governments should therefore make efforts to provide necessary funds for extension activities, and extension agencies should also make use of these funds judiciously to accomplish the task of improving turkey production in the study area. The communication gap between extension agents and farmers (3.3\%) and insincerity of veterinarians $(3.3 \%)$ were the least important problems associated with non-adoption of improved innovation.

\section{CONCLUSION AND RECOMMENDATIONS}

The study showed that the majority of the turkey farmers are female and work on a part-time basis. Half of the respondents were unaware of improved management practices. Since all respondents had formal education, they can readily adopt or accept innovations designed to improve turkey production in the area. It is therefore important for the government through its agencies to update turkey farmers on the existing improved management practices. Livestock and extension workers should help to spread up-to-date information on standard management practices to improve turkey production through print media such as pamphlets, posters, and leaflets, among others, to turkey farmers. Again, government should increase the number of extension agents to facilitate access to these turkey farmers in remote places in order to increase the rate of adoption of improved farm practices, which may boost the food security and economic power of the farmers.

Funding: This study received no specific financial support.
Competing Interests: The authors declare that they have no competing interests.
Authors' Contributions: All authors contributed equally to the conception and design of the
study.
Views and opinions expressed in this study are those of the authors views; the Asian Journal of
Agriculture and Rural Development shall not be responsible or answerable for any loss, damage,
or liability, etc. caused in relation to/arising out of the use of the content.

\section{REFERENCES}

Adeniji, A., \& Balogun, O. (2002). Utilisation of flavour treated blood-rumen content mixture in the diets of laying hens. Nigerian Journal of Animal Production, 29(1), 34-39. Available at: https://doi.org/10.51791/njap.v29i1.1502.

Ajala, M. K., \& Adesehinwa, A. O. K. (2006). Constraints of Turkey production in Zaria, Kaduna State, Nigeria. Tropical Journal of Animal Science, 9(2), 101-106.

Ajala, M. K., Nwagu, B. I., Sekoni, A. A., \& Adeshinwa, A. O. K. (2007). The profitability of Turkey production in Zaria, Kaduna state, Nigeria. Asian Journal of Information Technology, 6(1), 27-33.

Akbay, C. (2006). Animal products consumption patterns of rural households in Turkey. Livestock Research for Rural Development, 18(1), 1-9.

Alabi, A., \& Aruna, B. (2006). Econometric determination of contribution of family poultry to women's income in Niger-delta, Nigeria. Journal of Central European Agriculture, 7(4), 753-760.

Alam, S. M., \& Shaikh, A. H. (2007). Expanding poultry farming to rural areas. DAWN the internet edition. Karachi, Lahore, Islamabad. Pakistan.

Amaza, P. S. (2000). Resource use efficiency in food crop production in Gombe State. Unpublished Ph.D. Thesis. Department of agricultural Economics and Extension, Faculty of Agriculture, Usmanu Danfodiyo University Sokoto, Nigeria.

Amos, T. (2006). Analysis of backyard poultry production in Ondo State, Nigeria. International Journal of Poultry Science, 5(3), $247-$ 250. Available at: https://doi.org/10.3923/ijps.2006.247.250.

Apantaku, S. (2006). Analysis of participation of farmers in participatory poultry production research in Lagos State, Nigeria. Livestock Research for Rural Development, 18(7), 1-10.

Asli, M. M., Hosseini, S. A., Lotfollahian, H., \& Shariatmadari, F. (2007). Effect of probiotics, yeast, vitamin E and vitamin C supplements on performance and immune response of laying hen during high environmental temperature. International Journal of Poultry Science, 6(12), 895-900. Available at: https://doi.org/10.3923/ijps.2007.895.900.

Atteh, J. O. (2002). Principles and practice of livestock feed manufacturing, Adlek Printers 64. Nigeria: Sabo-line Ilorin.

Ayanda, I. (2013). Capability of poultry association of Nigeria for extension services delivery to poultry farmers in Kwara State, Nigeria. Journal of Agricultural Extension, 17(2), 7-15.

Ayichi, D. (1995). Models of rural development with special focus on ADP's, in Ebo et al, Rural Development in Nigeria: Concepts, processes and prospects (ed). Lagos: Concept Publications.

Biswas, A., Mohan, J., \& Sastry, K. (2010). Effect of vitamin E on production performance and egg quality traits in Indian native Kadaknath hen. Asian-Australasian Journal of Animal Sciences, 23(3), 396-400.

Brocholt, G., \& Odgaard, P. (2009). Women and Chicken: Traditional poultry management in Nicaragua and Tanzania. (Eds): Y. Peters, K. Johnson, V. Lucas and C. Oscar. Paper presented at the Proceedings of Development Workers Course on Poultry as a Tool in Poverty Eradication and Promotion of Gender Equality. Time Landboskole, Denmark. 22-26 May, 2009.

Bureau, D. P., \& Cho, C. Y. (2000). An introduction to nutrition and feeding of fish. Guelph, Canada: University of Guelph, Fish Nutrition Research Laboratory.

Ciftci, M., Ertas, O. N., \& Guler, T. (2005). Effects of vitamin E and vitamin C dietary supplementation on egg production and egg quality of laying hens exposed to a chronic heat stress. Veterinary Medicine Journal, 156(2), 107-111.

Dikmen, B. Y., Ipek, A., Şahan, Ü., Petek, M., \& Sözcü, A. (2016). Egg production and welfare of laying hens kept in different housing systems (conventional, enriched cage, and free range). Poultry Science, 95(7), 1564-1572. Available at: https://doi.org/10.3382/ps/pew082. 
Fawole, O. P. (2006). Poultry farmers' utilization of information in Lagelu local government area of Oyo State, Nigeria. International Journal of Poultry Science, 5(5), 499-501.

Gildemacher, P., Maina, P., Nyongosa, M., Kinyae, P., Woldegiorgis, G., Lema, Y., . . Oriz., O. (2009). Participatory analysis of the potato knowledge and information system in Ethiopia, Kenya and Uganda. " In Sanginga, PC, Waters-Bayers, A, Kaaria, S, Njuki, J, and Wettasinha, C (eds.) (pp. 153-165). Earthscan: London: Innovation Africa: Enriching farmers' livelihoods.

Goetting, V., Lee, K., \& Tell, L. A. (2011). Pharmacokinetics of veterinary drugs in laying hens and residues in eggs: A review of the literature. Journal of Veterinary, Pharmacology and Therapeutics, 34(6), 521-556.

Ironkwe, M. O., \& Akinola, L. F. (2010). Profitability of Turkey production in Ahoada East Local Government Area of Rivers State, Nigeria. Continental Journal of Agricultural Science, 4(2), 38-41.

Ja'afar-Furo, M., Balla, H., \& Yakubu, B. (2007). Avian influenza (bird flu) outbreak news scare and its economic implication on poultry enterprises in Adamawa state, Nigeria. Global Journal of Agricultural Sciences, 6(1), 61- 68. Available at: https://doi.org/10.4314/gjass.v6i1.2302

Ja'afar-Furo, M. R., Balla, H. G., Tahir, A. S., \& Haskainu, C. (2008). Incidence of avian influenza in Adamawa State, Nigeria: The epidemiology, economic losses and possible role the wild birds play in the transmission of the disease. Global Journal of Agricultural Sciences, 8(2), 205-217. Available at: https://doi.org/10.3923/jas.2008.205.217.

Ja'afar-Furo, M., \& Gabdo, B. (2010). Identifying major factors of poultry production as sustainable enterprise among farmers using improved methods in rural Nigeria. International Journal of Poultry Science, 9(5), 459-463. Available at: https://doi.org/10.3923/ijps.2010.459.463.

Jacob, J. P., Wilson, H. R., Miles, R. D., Butcher, G. D., \& Mather, F. B. (2014). Factors affecting egg production in backyard chicken flocks. FACT SHEET PS-35 of the Institute of Food and Agricultural Sciences (IFAS) Extension (pp. 1 - 8): University of Florida.

Kehinde, A. S., Babatunde, T. O., Ayoola, O. A., \& Temowo, O. O. (2006). Effect of different levels of protein on the growth performance characteristics of broiler chicks. Paper presented at the Proc. 31st Ann. Conf Nig. Soc. for Anim. Prod. (NSAP), March 12th - 15th Bayero University, Kano.

Kwaghe, P. V., Amaza, P. S., \& Ja'afar-Furo, M. R. (2009). The relationship between social factors and thee poverty experienced by farming households in Borno State. Nigeria: Global Journal of Agricultural Sciences.

Mapiye, C., \& Sibanda, S. (2005). Constraints and opportunities of village chicken production systems in the smallholder sector of Rushinga district of Zimbabwe. Livestock Research for Rural Development, 17(10), 2005.

Mozdziak, P. (2019). Species of meat animals: Poultry. Reference Module in Food Science (pp. 1-6). United States of America: Elsevier Inc, Academic Press.

Musa, D. B., Dabai, J., Sakaba, A., \& Sanchi, I. (2015). Constraints to smallholder Turkey production in Zuru Emirate, Kebbi State, Nigeria. Global Journal of Animal Scientific Research, 3(1), 171-177.

Nielsen, H., Roos, N., \& Thilsted, S. H. (2003). The impact of semi-scavenging poultry production on the consumption of animal source foods by women and girls in Bangladesh. The Journal of Nutrition, 133(11), 4027S-4030S. Available at: https://doi.org/10.1093/jn/133.11.4027s.

NPC. (2006). Report of Nigeria's national population commission on the 2006 Census Population and Development Review. 33(1), 206-210.

Nwagu, B. I. (2002). Production and management of indigenous poultry species. Paper presented at the Training Manual, National Animal Production Research Institute (NAPRI), Federal Ministry of Agriculture and Rural Development, Ahmadu Bello University (ABU) Zaria.

Oakeley, R. (1999). The socio-economic environment of Newcastle disease control strategies for backyard poultry systems. Paper presented at the Proceedings of a Workshop-Poultry as a Tool in Poverty Eradication and Promotion of Gender Equality.

Ogunlade, I., \& Adebayo, S. (2009). Socio-economic status of women in rural poultry production in selected areas of Kwara State, Nigeria. International Journal of Poultry Science, 8(1), 55-59. Available at: https://doi.org/10.3923/ijps.2009.55.59.

Ogunniyi, A., \& Kehinde, O. (2015). Impact of agricultural innovation on improved livelihood and productivity outcomes among smallholder farmers in Rural Nigeria. Paper presented at the A Paper Prepared for Presentation at the 5th Maastricht School of Management (MSM) 5th Annual Research Conference Managing African Agriculture: Markets, Linkages and Rural Economic Development 4 September 2015, MSM, Maastricht, The Netherlands.

Oguz, F. K., Oguz, M. N., Buyukoglu, T., \& Sahindokuyucu, F. (2010). Effects of L-carnitine and vitamin C-electrolyte premix supplementation to diet containing safflower seed on performance, egg quality and some serum parameters in quails under summer condition. Journal of Animal and Veterinary Advances, 9(8), 1212-1215.

Okitoi, L. O., Ondwasy, H. O., Obali, M. P., \& Murekefu, F. (2007). Gender issues in poultry production in rural household of Western Kenya. Livestock Research for Rural Development, 19(2), 205-210.

Onwumere, J., \& Obasi, R. (2010). Analysis of small-scale turkey production in owerri agricultural Zone of Imo State, Nigeria. International Journal of Agriculture and Rural Development, 13(2), 36-39.

Ovwigho, B., Bratte, L., \& Isikwenu, J. (2009). Chicken management systems and egg production in Delta State Nigeria. International Journal of Poultry Science, 8(1), 21-24.

Oyeagu, C. E., Ani, A. O., Egbu, C. F., Akpolu, E. S., Iwuchukwu, J. C., \& Omumuabuike, J. N. (2015a). Performance of broiler finisher birds fed toasted bambara nut (vigna subterranean (L) verdc) offal with supplementary Enzyme. Asian Journal of Science and Technology, 6(1), 934-939.

Oyeagu, C. E., Ani, A. O., Egbu, C. F., Udeh, F. U., \& Omumuabuike, J. N. (2015b). Comparative performance of Nera Black and Shaver Brown hen fed self-Compounded and Commercial Layers' diet. Asian Journal of Science and Technology, 6(1), 940946.

Oyeagu, C., Ani, A., Egbu, C., Udeh, F., Omumuabuike, J., \& Iwuchukwu, J. (2016). The effect of feeding toasted bambara nut (Vigna subterranean verdc) offal and supplementary enzyme on performance of broiler chicks. Tropical Agriculture, 93(4), 271283.

Panda, A., Ramarao, S., Raju, M., \& Chatterjee, R. (2008). Effect of dietary supplementation with vitamins E and C on production performance, immune responses and antioxidant status of White Leghorn layers under tropical summer conditions. British Poultry Science, 49(5), 592-599. 
Pornpun, P., Bunchasak, C., Rakangthong, C., \& Poeikhampha, T. (2014). Effects of adding vitamins and organic acids into the drinking water on growth performance, carcass yield and meat quality of broilers raised under tropical condition. Journal of Applied Sciences, 14(24), 3493-3499.

Renaudeau, D., Collin, A., Yahav, S., De Basilio, V., Gourdine, J.-L., \& Collier, R. (2012). Adaptation to hot climate and strategies to alleviate heat stress in livestock production. Animal, 6(5), 707-728.

Salo, S., Tadesse, G., \& Hilemeskel, D. (2016). Village chicken production system and constraints in Lemo District, Hadiya Zone, Ethiopia. Poultry, Fisheries \& Wildlife Sciences, 4(2), 158-162.

Sherwin, C., Richards, G., \& Nicol, C. (2010). Comparison of the welfare of layer hens in 4 housing systems in the UK. British Poultry Science, 51(4), 488-499.

Sinkaiye, T. (2005). Agricultural extension participatory methodologies and approaches', in S.F. Afolayan (ed.), Agricultural Extension in Nigeria (pp. 220-233). Nigeria: AESON, Ilorin.

Sobayo, R. A., Oguntona, E. B., Osinowo, O. A., Eruvbetine, D., Barngbose, A. M., Oso, O. A., . . Adeyemi, O. A. (2008). Effects of ascorbic acid sipplementation on the performance and egg quality of laying birds in a humid environment. Paper presented at the Proc. Of the 13th Ann. Conf of the An. Sc. Assoc. of Nig. (ASAN) Sept.

Ugwu, S., Ogbu, C., \& Amaechi, C. (2011). Effect of soil type and soil depth on the reproductive performance of two species of giant African land snails in the humid tropics. International Journal of Science and Nature, 2(2), 176-182. 